\title{
Evaluation of different weeders for drudgery reduction of farm women in Jharkhand
}

\author{
V.K. PANDEY, R.K. SINGH, V.P. RAI AND D. ORAON
}

Received : 23.06.2017; Revised : 18.08.2017; Accepted : 03.09.2017

See end of the Paper for authors' affiliation Correspondence to :

\section{V.K. PANDEY}

Krishi Vigyan Kendra (B.A.U.), CHATRA (JHARKHAND) INDIA Email : vinod.bau@ rediffmail. com
- ABSTRACT : Weeds are the most under estimated crop pest in tropical agriculture, although they cause higher reduction in crop yield than other pest and disease. In agriculture rural women play a vital role for maximum operation of crop production. Drudgery reduction has a serious problem for farm women in this respect the present research assess three types of weeders on ergonomic parameters, man days required with a view to promote health. The experiment was conducted in Gidhour village of Chatra district, Jharkhand, 20 farm women in the group age of 25 to 35 years were selected in normal health. The result revealed that all three weeder proved efficient on ergonomic parameters reduced working heart beat energy and cast of cultivation compared to traditional tools (Spade). Among all three weeders grubber (Three tynes) with wheel was best weeder in respect to reduction of working heart beat energy expenditure and cost of cultivation. The yield of cauliflower was highest (278q/ha) in technology option grubber (three tynes) with wheel.

- KEY WORDS : Weeder, Energy, Expenditure, Heart beat, Mandays

-HOW TO CITE THIS PAPER : Pandey, V.K., Singh, R.K., Rai, V.K. and Oraon, D. (2017). Evaluation of different weeders for drudgery reduction of farm women in Jharkhand. Internat. J. Agric. Engg., 10(2) : 474-476, DOI: 10.15740/HAS/IJAE/10.2/474-476. 